\title{
Hallvard Kjelen
}

Fakultet for lcererutdanning, kunst og kultur

Nord universitet

E-post: hallvark@hinesna.no

\section{Grunnleggjande fagleg? \\ Framstillinga av fagleg innhald, grunnleggjande ferdigheiter og eleven i fagplanane for norsk og musikk}

\section{Samandrag}

Denne artikkelen tek føre seg forholdet mellom fag og grunnleggjande ferdigheiter. Gjennom ein analyse av Kunnskapsløftets fagplanar for norsk og musikk freistar eg å vise korleis dei grunnleggjande ferdigheitene er integrerte $i$ faga på ulike måtar. Norskfaget er konstruert som eit literacyfag der det faglege innhaldet $i$ nokon grad kan synast å vere underordna oppøvinga av grunnleggjande ferdigheiter. I musikkfaget er dei grunnleggjande ferdigheitene betre integrert i det musikkfaglege, og faget står tydelegare fram. Det er dermed grunn til å hevde at dei grunnleggjande ferdigheitene ikkje berre inngår i faga på fagas premiss slik rammeverket legg opp til. Det er òg slik at fagkonstruksjonane $i$ varierande grad er tilpassa dei grunnleggjande ferdigheitene.

Nøkkelord: lereplanar, norskfaget, musikkfaget, grunnleggjande ferdigheiter, literacy, fagspesifikke ferdigheiter

\section{Abstract}

This article discusses the relationship between subjects and basic skills. Through an analysis of The Knowledge Promotion's curricula for Norwegian language arts and music, I show how the five basic skills identified in the Knowledge Promotion are integrated into the subjects in different ways. Norwegian is designed as a literacy subject, where the subject content to some extent appears to be subordinated to the development of basic skills. In music, the basic skills are better integrated into the subject, and the subject stands out more clearly against the background. One may thus reasonably claim that the basic skills are not only included in the subjects on the subject's terms, which is the aim of the framework. The subjects are to varying degrees adapted to the basic skills.

Keywords: curriculum, basic skills, literacy, subject-spesific literacy, language arts, music 


\section{Innleiing}

Føremålet med denne artikkelen er å setje lys på korleis fagplanane ${ }^{1}$ i musikk og norsk presenterer fagleg innhald og dei grunnleggjande ferdigheitene. Biletet som plantekstane teiknar av eleven blir òg drøfta. Ein analyse av fagplanane viser at forholdet mellom grunnleggjande ferdigheiter og fagleg innhald er skildra til dels svært ulikt i desse to fagplanane.

\section{Bakgrunn og problemstilling}

Den norske læreplanreforma Kunnskapsløftet er ei literacyreform (Berge, 2005). Literacyomgrepet som ligg til grunn for fagplanane i Kunnskapsløftet (LK06), er breitt og funksjonelt. Det vil seie at literacy handlar om å øve opp kunnskapar og ferdigheiter som gjer at ein kan «delta og fungere i samfunnets og hverdagslivets ulike literacy-hendelser (...)» (Skovholt 2014, s. 17). Literacy er på denne måten forstått i ei sosiokulturell ramme, som grunnleggjande og generelle ferdigheiter eller kompetansar. Literacyomgrepet som ligg til grunn for fagplanane i Kunnskapsløftet kan ein sjå i samanheng med omgrepet nøkkelkompetanse som OECDs DeSeCo-dokument omhandlar (DeSeCo, 2005). OECDs dokument peiker på at samfunnet i dag er så komplekst, og dei utfordringane som individa blir stilte overfor, er så samansette og ulike at det ikkje er mogleg å lage ei uttømmande liste over naudsynte kompetansar. Nøkkelkompetansane må derfor vere generelle, og dei kan ikkje dreie seg om "the basic reproduction of accumulated knowledge" (DeSeCo, 2005, s. 8). Det er likevel ein føresetnad for OECD at desse nøkkelkompetansane kan lærast gjeve gode læringsmiljø. DeSeCo-dokumentet grupperer kompetansane i tre kategoriar: interaktiv bruk av verktøy (språk, teknologi), samhandling i heterogene grupper og autonom handling. Literacy eller skriftkyndigheit heng nøye saman med den første kategorien. I den norske læreplanen blir omgrepet grunnleggjande ferdigheiter bruka nokolunde synonymt med omgrepet kompetanse, og det gjev god meining å sjå dei i samanheng med DeSeCos nøkkelkompetansar. Dette kan vere noko problematisk i og med at omgrepet ferdigheit (jf. det engelske skill) helst konnoterer noko snevrare og meir instrumentelt enn det som ligg i omgrepet kompetanse (Hertzberg 2010). I DeSeCo-dokumentet er kompetanse definert som «(...) the ability to meet complex demands, by drawing on and mobilising psychosocial resources (including skills and attitudes) in a particular context» (DeSeCo, 2005, s. 4). På denne måten er ferdigheiter (skills) å forstå som berre eit aspekt ved kompetanseomgrepet. Det er vidare mogleg å argumentere for at OECDs nøkkelkompetansar tangerer eit meir tradisjonelt danningsomgrep (sjå Smidt, 2011).

Dei fem grunnleggjande ferdigheitene (å kunne skrive, å kunne lese, å kunne rekne, munnlege ferdigheiter og digitale ferdigheiter) skal ein forstå som «redskaper for læring i alle fag og samtidig en forutsetning for at eleven skal 
kunne vise sin kompetanse.» (Utdanningsdirektoratet, 2012). Dei er dermed å forstå som fagovergripande kompetansar (Shanahan og Shanahan, 2012). Forholdet mellom faglege ferdigheiter og grunnleggjande ferdigheiter er ikkje avklara:

[N]år ferdighetene ofte omtales for seg, og da som fagovergripende, undergraves sammenhengen mellom fag og ferdigheter. Ferdighetene forblir abstrakte fremmedelementer for faglærere, og en stor mulighet for å gjøre faget relevant og praktisk for elevene går forbi uutnyttet. En avklaring av forholdet mellom fag og ferdigheter er avgjørende for at ikke fokuset på «å kunne løse oppgaver og møte utfordringer» i Fremtidens skole skal bli en ny abstraksjon (Skaftun, Wagner og Aasen, 2015).

Med utgangspunkt i Shanahan og Shanahan (2012) kan ein, slik Skaftun, Wagner og Aasen har gjort for norskfagets del, diskutere fagspesifikk literacy (disiplinary literacy) og fagovergripande literacy (content area literacy) med eit fagdidaktisk blikk.

I rammeverket for grunnleggjande ferdigheter, eit arbeidsverktøy laga i samband med fagplanrevisjonane i 2013, heiter det at måla for ferdigheitene skal vere integrerte i kompetansemåla «på premissene til det enkelte faget», og at ferdigheitene difor er «uttrykt på ulik måte og i varierende grad i læreplanene, avhengig av hvordan ferdighetene blir forstått i faget, og hvilken funksjon de har som en del av kompetansen i faget» (Utdanningsdirektoratet 2012, s. 5). Intensjonen er altså at grunnleggjande ferdigheiter skal integrerast i faga, og at det er fagas eigenart som skal vere styrande for korleis arbeidet med dei grunnleggjande ferdigheitene skal inngå.

Dersom ein skal la fagas eigenart vere styrande for integrering av grunnleggjande ferdigheiter i faga, må ein ta stilling til kva eit fags eigenart er. Vidare er det grunn til å undersøke om, og i så fall i kva grad, fagkonstruksjonane i dei ulike planane er tilpassa dei grunnleggjande ferdigheitene. I kva grad har til dømes ideen om «det norskfaglege» vorte farga av dei grunnleggjande ferdigheitene?

Engelsen og Karseth (2007) peiker i sin analyse av Kunnskapsløftet på at dei ulike delane som læreplanen består av (generell del, prinsippdelen, (Udir, 1993) Læringsplakaten (Udir, 2006c) og fagplanane (Udir, 2006a)), har forskjellig ideologisk innretning, og representerer ulike kunnskapssyn. Medan den generelle delen er innhaldsdriven og har eit preg av nykonservativ tradisjonalisme, er fagplanane måldrivne og kan seiast å representere teknisk instrumentalisme. «Kunnskapssynet bak disse tekstene beskriver ikke utdanning som et kulturelt prosjekt. (...) Skolens oppgave blir først og fremst å sikre at elevene utvikler de kompetanser som en antar at arbeidslivet trenger» (Engelsen og Karseth, 2007, s. 410). Engelsen og Karseth etterlyser, med utgangspunkt i Klafkis danningsteori, ei dreiing mot tidstypiske nøkkelproblem, altså noko meir innhaldsorientert enn nøkkelkompetansar. Kunnskapsløftets fokus på 
grunnleggjande ferdigheiter meiner dei er eit problem fordi dette lèt fagleg innhald vere sekundært og gjenstand for lokale val (sjå òg Karseth og Sivesind, 2009). I ein danningsteoretisk didaktikktradisjon vil spørsmålet om innhald vere det viktigaste, innanfor ein læreteoretisk didaktikkforståing, som no er dominerande i Noreg og Norden, har ikkje innhaldskategorien større vekt enn andre didaktiske kategoriar, snarare er det slik at spørsmålet om innhald er hamna i bakgrunnen (Nielsen, 2009). Frede V. Nielsen (2009) forstår rett nok omgrepet innhald slik at det omfattar både ferdigheiter og kunnskap, og han deler innhald inn i fire «genstandsfelter»: Fenomen-feltet (til dømes litterære tekstar), realia- og kontekst-feltet (til dømes historiske hendingar), det faglige aktivitets- og metodefeltet (fagspesifikke metodar og aktivitetar, i norskfaget typisk litterær analyse og skriving av tekstar) og det personlege og sosiale erfaringsfeltet.

Denne artikkelen vil, med fagdidaktisk optikk, ta føre seg forholdet mellom fagleg innhald i slik vid forstand og grunnleggjande ferdigheiter etter Kunnskapsløftet. Følgjande spørsmål ligg til grunn:

Korleis er grunnleggjande ferdigheiter integrerte i fagplanane for norsk og musikk?

\section{I tillegg spør eg:}

Kva bilete av eleven på den eine sida, og norskfaglege og musikkfaglege innhaldskategoriar på den andre sida blir avteikna i fagplantekstane, og på kva måte er grunnleggjande ferdigheiter ein del av dette biletet?

Spørsmål som dette er særleg relevante å stille i arbeidet med fornying av Kunnskapsløftet, der òg djup læring og eit breiare kunnskapssyn er mellom temaa som skal diskuterast (jf. Meld. St. 28 (2015-2016), 2016, NOU 2014: 7 og NOU 2015: 2015: 8).

\section{Metodologi og materiale}

Presentasjonen baserer seg på kritiske, komparative lesingar av Kunnskapsløftets fagplanar for norsk og musikk (Utdanningsdirektoratet, 2006b og 2013). Desse fagplanane er undersøkingas materiale. I analysane har eg særleg retta eit blikk mot korleis faglege innhaldskategoriar (Nielsen, 2009) er presenterte, kva metaforar og omgrep som er brukte om faget og om elevane, og korleis idear om elevroller og faglegheit er framstilte språkleg i plantekstane. Ettersom analysane på denne måten har vore retta vel så mykje mot form og uttrykksmåtar som innhald, er det nærliggjande å seie at dette er ei 
litteraturvitskapeleg nærlesing (Gallop, 2007, Olsen, 2003, Skaftun og Michelsen, 2017, s. 42).

Læreplanar er grunnleggjande kompliserte tekstar. På avsendarsida kan ein ikkje forankre læreplanane til ein bestemt forfattar, og mange står bak som tekstprodusentar. Vidare, og det gjeld særleg planar som er reviderte, er formuleringar komne til over tid, og nokre formuleringar er «arva» frå tidlegare rundar. På denne måten kan ein finne spor etter ulike posisjonar og diskursar i den same teksten. Læreplantekstar kan dermed vere særleg fulle av motsetnader og inkonsekvensar. Læreplanar er vidare retta mot ulike mottakarar (politikarar, skuleleiarar, lærarar og foreldre), og skal fungere på ulike nivå: som skulepolitisk dokument og som praktisk rettleiing for dei som planlegg og gjennomfører undervisning. Samanhengen mellom ein læreplans politiske funksjon (legitimering av innhald), programmatiske funksjon (produksjon av innhald) og praktiske funksjon (læreplanen som ramme for undervisning) (Gundem, 2008, s. 59), er samansett. Kva rolle har til dømes føremålsformuleringar (legitimering) i lærarars planlegging av undervisning? I denne artikkelen er det særleg læreplanens politiske funksjon som blir diskutert.

Alle fagplanane i Kunnskapsløftet følgjer same struktur. Eg har særleg konsentrert meg om å jamføre avsnitta «Formål» og «Grunnleggende ferdigheter», men òg avsnitta med kompetansemål er tekne med i analysen.

Norskplanen og musikkplanen er valt fordi desse faga på ein måte står nær kvarandre. Dei er kulturfag, dei er fag der estetiske uttrykk enten er hovudsaka (musikk) eller tradisjonelt har vore eit sentralt innhaldsmoment (norsk). Men det er òg mykje som skil faga frå kvarandre, ikkje minst når det gjeld korleis dei er vektlagde i skulen. Norsk har eit timetal i ungdomsskulen på 398, musikk har berre 83. Vidare er det slik at norskfaget lenge òg har vore forstått som eit reiskapsfag eller ein leverandør av meir generelt brukbare verktøy. Til musikkfaget er det ikkje knytt mange slike forventningar. Eit problemfelt i norskfaget er, og har lenge vore, den såkalla «emnetrengselen», det vil seie at mange ser norskfaget som for vidt, omfattande, for ufokusert og med for uklare grenser. Herman Ruge peiker allereie i 1933 på morsmålfagets utydelege grenser:

Et hvilket som helst annet fag har sin klare og naturlige avgrensning (geografi, naturhistorie, matematikk). Men morsmålet strekker seg så langt som der finnes et saklig innhold og en menneskelig hjerne til å gi innholdet navn (Ruge, 1933, s. 8).

Sjølv om faga har endra seg historisk, og Ruges påstand om «naturlig avgrensning» ikkje gjeld på same måte i dag, er spørsmålet om emnetrengsel ikkje tematisert på same måte i alle skulefaga.

Det er viktig å peike på at dei følgjande analysane berre seier noko om fagkonstruksjonane i fagplantekstane. Med læreplanforskaren John I. Goodlad (1979) kan vi seie at det er den formelle fagplanen og i nokon grad det 
ideologiske nivået som er gjenstand for analysane i denne artikkelen. Den oppfatta, operasjonaliserte og erfarte fagplanen er ikkje gjenstand for denne undersøkinga. Avstanden mellom formell fagplan og operasjonalisert fagplan eller faktisk undervisning, har truleg fagbestemte variasjonar. Ei undersøking av musikklærarars kompetanse og læreplanforståing viser til dømes at mange musikklærarar har særs lite formell kompetanse i musikk, og at dette fører til store forskjellar i den faktiske musikkundervisninga (Sætre, Neby, Ophus, 2016). For norskfagets del er dette biletet truleg annleis, særleg ettersom åtte av ti norsklærarar i grunnskulen har fagleg fordjuping (Lagerstrøm, Moafi og Revold, 2014).

\section{Fagkonstruksjonar i plantekstane}

\section{Fagleg føremål}

I det innleiande avsnittet om fagets føremål blir norskfaget definert som «et sentralt fag for kulturforståelse, kommunikasjon, dannelse og identitetsutvikling» (Udir, 2013). Det kjem ikkje fram i teksten kva som er forholdet mellom desse overordna omgrepa. Vidare blir faget framstilt som ein arena for dialog: «Norskfaget åpner en arena der [elevane] får anledning til å finne sine egne stemmer, ytre seg, bli hørt og få svar» (Udir, 2013). Her er det ganske tydeleg ei bakhtinsk forståing av dialog og kommunikasjon som ligg til grunn. Ein arena var opphavleg ein kampplass. Det er nok ikkje den valdelege valøren av ordet som er intendert i fagplanteksten, men om ein les litt vidare kjem ein fort til ordet «strategi», eit ord med militært og valdeleg opphav knytt til strid: «Faget skal motivere til lese- og skrivelyst og bidra til å utvikle gode læringsstrategier» (Udir, 2013). Når eit fag slik blir framstilt som ein arena der ein òg skal nytte ulike strategiar, manar det fram eit ganske tydeleg bilete av den ideelle eleven. Ho er aktiv og handlar strategisk, men ikkje valdeleg all den stund våpena som er i bruk berre er språklege. Eleven skal «stå fram med meninger og vurderinger» (Udir, 2013). Arenaen er ein open stridsplass, og gjev ikkje moglegheit til å gøyme seg eller trekkje seg unna.

Norskfaget blir på den eine sida presentert som ein leverandør av ferdigheiter som òg er viktige for andre fag: «Muntlige ferdigheter, lese- og skrivekompetanse er både et mål i seg selv og et nødvendig grunnlag for læring og forståelse i alle fag på alle trinn» (Udir, 2013). Det går på den andre sida ikkje veldig klart fram kvar grensene for det spesifikt norskfaglege går; norskfaget som blir konstruert i planverket er først og fremst romsleg. Det skal handle om eit mangfald av tekstar: «Faget bygger på et tekstbegrep som inkluderer muntlige, skriftlige og sammensatte tekster (...)» (Udir, 2013) og elevane skal lese både sakprosa og skjønnlitteratur. I prinsippet kan altså norskfaget romme ei uavgrensa mengd tekstar, og altså ikkje berre verbaltekstar (Kress, 2003; Rogne, 2008 og 2012). I den reviderte norskplanen frå 2013 ser vi altså at det langt på veg er eit medieøkologisk tekstomgrep som ligg til grunn. 
Det tekstlege innhaldet i faget er ikkje knytt til eit bestemt medium eller modalitet, men til tekstar meir generelt. I norskfaget skal elevane lære ulike lesemåtar og strategiar for tekstresepsjon og -produksjon, og utvikle ein fleksibel literacy (Rogne, 2012). Faget skal òg handle om språkleg mangfald:

I Norge er norsk og samisk offisielle språk, og bokmål og nynorsk er likestilte skriftlige målformer. Vi bruker mange ulike dialekter og talemålsvarianter, men også andre språk enn norsk. Det språklige mangfoldet er en ressurs for utviklingen av barn og unges språkkompetanse (Udir, 2013).

Vidare blir det klart at norskfaget både har ein synkron og ein diakron akse, og at det er i eit spenningsfelt mellom «det nasjonale og det globale» (Udir, 2013). Ein rest av diskursen om det nasjonsbyggande norskfaget er altså med her, men avstemt mot eit globalt perspektiv. Føremålsavsnittet gjer altså ikkje noko forsøk på ei fagleg avgrensing, tvert om ser det ut som at grensene for faget er gjort så vide og fleksible som mogleg. Mangfald, prosess, dynamikk og handling kjenneteiknar fagkonstruksjonen. Slik blir til dømes kulturarvomgrepet presentert: «Kulturarven er (...) en levende tradisjon som forandres og skapes på nytt, og norskfaget skal oppmuntre elevene til å bli aktive bidragsytere i denne prosessen» (Udir, 2013). Ein slik norskfagskonstruksjon står i klar kontrast til 1950-talets norskfag, altså det norskfaget som Inge Moslet kallar «vakkernorsk» (Moslet, 2009). Her var kulturarva noko elevane skulle tileigne seg.

Ein mogleg kostnad ved ein slik fagkonstruksjon som vi finn i Kunnskapsløftets norskplan kan vere at faget blir vanskelegare å gripe (jf. Kjelen, 2013). For det første kan ein forstå føremålsteksten i retning av at norskfaget langt på veg skal vere ein leverandør av grunnleggjande ferdigheiter, altså nøkkelkompetansar som ikkje er fagspesifikke:

Det er ikke nødvendigvis uheldig å betrakte norskfaget som et redskapsfag, men hvis man reduserer det til et fag med ansvar for lesing og skriving som fagovergripende ferdigheter, får man et svært mye dårligere redskap enn man kan få hvis man i stedet løfter fram og dyrker den norskfaglige lesingen og skrivingen som helhet, dvs. norskfagets literacy (Skaftun, Wagner og Aasen, 2015, s. 58).

For det andre er det «tradisjonelt» norskfaglege i veldig liten grad avgrensa i føremålsavsnittet. I staden for ein meir eller mindre fast nasjonal litterær kanon, skal faget ta føre seg ei uavgrensa tekstmengd, og setje i spel eit språkleg mangfald som skal vere «en ressurs for utviklingen av barn og unges språkkompetanse» (Udir, 2013).

Musikkfaget blir òg presentert som særs ope og rommeleg. Faget skal bidra til «mellommenneskelig forståelse på tvers av tid, sted og kultur» og skal ivareta «både musikalsk mangfold og sjangerbredde» (Udir, 2006b). Vidare skal faget innehalde dans, og det har teknologiske aspekt som kan «inngå i andre fags arbeid med teknologi og design» (Udir, 2006b). Det er såleis mogleg å kritisere 
musikkplanen for å vere instrumentell, musikkfaget skal tene diverse andre føremål (Varkøy, 2010). Likevel står musikkfaget fram med tydelegare konturar enn norskfaget: Faget handlar først og sist om resepsjon og produksjon av ulike musikalske uttrykk. Tilsvarande kan ein då seie om norskfaget at det skal handle om resepsjon og produksjon av tekstar. Men gjeve det vide tekstomgrepet som ligg til grunn, vil faggrensene vere vanskelegare å sjå.

Eleven i musikkfaget er ikkje ein strateg på ein arena, men kreativ og skapande. Eleven i norskplanen blir kasta ut i ein røyndom der den einskilde må «ytre seg, bli hørt og få svar» og «stå fram med meninger og vurderinger». Det er eleven som aktør i eit demokrati der språklege og retoriske ferdigheiter er avgjerande for deltakinga. For eleven i musikkfaget er det ikkje i like stor grad påkravd å stå fram med det eigne på ein arena. Ho er derimot oftare ein del av eit fellesskap som ytrar seg saman, til dømes slik: «I arbeid med musikk står den musikalske og menneskelige samhandlingen sentralt, og i musikkfaget skal samvær og samhandling balanseres mot mestring (...)» (Udir, 2006b).

Medan dei grunnleggjande ferdigheitene kjem til overflata fleire stader i føremålsavsnittet i norskfaget, er dei ikkje like tydeleg til stades i føremålsavsnittet i musikkplanen. Medan norskfagleg opplæring i tekstresepsjon og -produksjon så å seie er leverandør av grunnleggjande ferdigheiter, vil dei musikkfaglege ferdigheitene, til dømes å skape musikalske uttrykk, ikkje like opplagt vere «grunnleggjande» slik dette er definert i Kunnskapsløftet.

\section{Grunnleggjande ferdigheiter}

Avsnittet som handlar om korleis dei ulike grunnleggjande ferdigheitene skal integrerast i faga, er meir omfangsrikt i planen for norskfaget enn i planen for musikk. Dette kan ein setje i samanheng med at norskfaget i nokon grad blir forstått som hovudansvarleg for fleire grunnleggjande ferdigheiter. Den grunnleggjande ferdigheita «A kunne uttrykke seg muntlig» blir i musikkplanen direkte kopla opp mot musikkfaglege hovudområde: å synge og å snakke om musikkopplevingar. I norskfaget er dei munnlege ferdigheitene presentert i meir generelle vendingar, og ikkje direkte knytt til noko spesielt norskfagleg. Munnlege ferdigheiter i norsk er «å skape mening gjennom å lytte, samtale og tale, og tilpasse språket til formål og mottaker» (Udir, 2013). Det går rett nok fram at elevane skal «tilegne seg fagkunnskap ved å lytte aktivt og å forstå og å bruke det muntlige språket stadig mer nyansert og presist i samtaler om norskfaglige emner, problemstillinger og tekster (...)» (Udir, 2013, mi utheving). Men kva denne fagkunnskapen eller dei norskfaglege emna måtte vere, går heller ikkje her tydeleg fram.

Dette biletet er gjennomgåande i avsnitta om grunnleggjande ferdigheiter. I planen for musikk er dei grunnleggjande ferdigheitene knytt tett opp mot musikkfaget, i planen for norsk er ikkje banda like sterke. Den grunnleggjande ferdigheita å lese dreier i musikkfaget seg om «å kunne tolke og forstå ulike musikalske uttrykk, symboler, tegn og former for notasjon» (Udir, 2006b). Det 
er ganske avgrensa og spesifikt. I norskfaget er lesing «å skape mening fra tekster fra nåtid og fortid i et bredt utvalg sjangere» (Udir, 2013). Det er ikkje særleg spesifikt. Det er påfallande at det ikkje står noko om at norskfaget bør ha eit særleg ansvar for skjønnlitterære tekstar og for utvikling av litterær kompetanse, noko som ein må kunne forstå som fagspesifikk lesing i norskfaget, og som ein kunne forstå som eit norskfagleg literacyansvar (Skaftun, Wagner og Aasen, 2015). Skjønnlitteratur er ikkje nemnt i dette avsnittet om lesing som grunnleggjande ferdigheit i norsk.

Medan rekning i musikk er direkte knytt til musikkfaglege storleikar, er rekning i norsk «å tolke og forstå informasjon i tekster som inneholder tall, størrelser eller geometriske figurer» (Udir, 2013). Rekning som grunnleggjande ferdigheit i norsk er slik sett framstilt på eit meir generelt nivå, som like gjerne kunne høve for samfunnsfag eller naturfag. Rekning i musikk blir gjennomgåande framstilt som integrert i det musikkfaglege:

Å kunne regne i musikk innebærer å bli kjent med musikkens grunnelementer og ulike musikalske mønstre, variasjoner og former og å kunne beregne tid og rom i musikalske og kroppslige uttrykk. Gjennom gjenkjennelse og anvendelse av musikkens grunnelementer utvikles forståelse for hvordan ulike mønstre og strukturer preger kunstneriske og musikalske uttrykk (Udir, 2006b).

Det dreier seg om musikk som form og mønster, og det dreier seg om estetikk, sansar og kroppslegheit. Vidare er det presisert at elevane skal få forståing for dette gjennom gjenkjenning og bruk av «musikkens grunnelementer». Musikkens grunnelement lèt seg langt på veg forstå ved hjelp av matematiske omgrep, til dømes kan ein ordne tonekvantitet i eit brøksystem. Det er slik sett ikkje merkeleg at rekning som grunnleggjande ferdigheit er lettare å integrere i musikkfaget enn i norskfaget.

\section{Kompetansemål}

Omfanget av kompetansemål er rimelegvis noko større i norskfaget enn i musikk. I norsk er det til dømes 23 kompetansemål etter 2. årstrinn, i musikk er det 13. I planen for norskfaget er samanhengen mellom kompetansemåla i faget og dei grunnleggjande ferdigheitene særs tett. I byrjaropplæringa i norsk er naturleg nok dei fleste av kompetansemåla knytt til oppøving av elementær literacy. Dette er særleg tydeleg i kompetansemåla under emneområdet skriftleg kommunikasjon etter andre klasse. Relativt tidleg dukkar det opp nokre kompetansemål som dekkjer det vi kan kalle fagspesifikt innhald, eller innhald som kan sjåast i samanheng med eit basisfagleg nivå (jf. Nielsen, 2004 og 2009), til dømes skal ein elev etter andre klasse kunne «samtale om begrepene dialekt, bokmål og nynorsk» og «samtale om personer og handling i eventyr og fortellinger».

Vidare i utdanningsløpet blir det gradvis lettare å sjå innhaldsmomenta som fagplanen nemner i samanheng med basisfaglegheit, eller dei ulike vitskapsfaga 
som norskfaget byggjer på. Relativt mange kompetansemål er gjennom heile løpet knytt til det vi må forstå som del av dei grunnleggjande ferdigheitene i lesing, skriving, munnleg språkbruk og digitale ferdigheiter. Under hovudområdet munnleg kommunikasjon skal elevar etter andre klasse kunne «lytte etter, forstå, gjengi og kombinere informasjon» (Udir, 2013). Etter 10. årstrinn skal eleven kunne «lytte til, oppsummere hovedinnhold og trekke ut relevant informasjon i muntlige tekster» (Udir, 2013). Dette er ein meir generell, eller grunnleggjande, kompetanse som sjølvsagt er relevant for alle fag. For tiande klasse er to av måla under dette hovudområdet knytt til emneområde som vi kan kalle «eksklusivt» norskfaglege: å forstå svensk og dansk tale og å samtale om litteratur, teater og film og «framføre tolkende opplesning og dramatisering» (Udir, 2013).

I planen for musikk inneheld dei aller fleste kompetansemåla for alle årstrinn eit eller fleire ord som først og fremst er musikkfaglege, til dømes klang, komponere, rytme, melodi, instrument eller lyd. Til dømes er kompetansemåla under hovudområdet musisering etter andre klasse formulert slik:

Mål for opplæringen er at eleven skal kunne

- bruke stemmen variert i ulike styrkegrader og tonehøyder

- imitere rytmer og korte melodier i ulike tempi, takt- og tonearter

- improvisere enkle stemmer og rytmer etter gehør

- delta i leker med et variert repertoar av sanger, rim, regler, sangleker og danser

- delta i framføring med song, samspill og dans (Udir, 2006b)

Alle kulepunkta her representerer såleis innhaldsmoment (i vid forstand, jf. Nielsen, 2009) som ein kan setje i direkte samanheng med vitskapsfaget og studiefaget musikk.

\section{Diskusjon og konklusjon}

Denne analysen har vist at det er store skilnader mellom framstillinga av norskfaget og musikkfaget i fagplanane. Analysen av planane viser at Kunnskapsløftet som literacy-reform ikkje har fått same innverknad på alle skulefaga, og at samanhengen mellom fagleg innhald og fagspesifikke ferdigheiter på den eine sida, og grunnleggjande, fagovergripande ferdigheiter eller såkalla nøkkelkompetansar ikkje alltid er godt definert og skildra i fagplanane. Ei vidare undersøking med tilsvarande optikk av dei andre skulefaga, ville gjeve eit fyldigare bilete.

Omgrepet grunnleggjande ferdigheiter, har uunngåeleg fått noko å seie for korleis ein tenkjer om dei einskilde skulefaga. Dei grunnleggjande ferdigheitene som er valt ut ligg særleg tett opp mot føremåla og kompetansemåla i bestemte 
fag. Det er i mange høve vanskeleg å skilje ut grunnleggjande ferdigheiter i norsk frå fagspesifikke ferdigheiter i norsk, altså det vi kan kalle disiplinær literacy (Shanahan og Shanahan, 2012). Dermed er det ikkje berre slik at dei grunnleggjande ferdigheitene inngår $i$ faga på fagas premiss slik rammeverket for grunnleggjande ferdigheiter legg opp til. Det kan òg synast å vere slik at fagkonstruksjonane slik dei ligg føre i fagplanane er tilpassa dei grunnleggjande ferdigheitene. Det kan òg synast som at det er ei meir generell oppfatning at visse fag er leverandørar av grunnleggjande ferdigheiter (norsk, matematikk), medan andre fag ikkje har så mykje med grunnleggjande ferdigheiter å gjere i det heile. Konsekvensen av dette kan bli at fag som ikkje er slike ferdigheitsleverandørar, til dømes musikk, då fort kan bli oppfatta som mindre viktige (Kalsnes, 2010, s. 71).

Planane for musikk og norsk skil seg frå kvarandre på den måten at dei grunnleggjande ferdigheitene i fagplanen for musikk i større grad synest å vere integrerte i det musikkfaglege. Både i føremålsavsnittet og i kompetansemåla er musikkfaget framstilt som nokså klart avgrensa, og dei grunnleggjande ferdigheitene er underordna dei spesifikt musikkfaglege ferdigheitene. For rekning som grunnleggjande ferdigheit har musikkfaget nokre føremoner ettersom så mange element i faget kan forståast i matematiske termar. Rekning som grunnleggjande ferdigheit er derimot ikkje knytt til noko spesifikt norskfagleg i formuleringane i norskplanen. Det kunne vore gjort i større grad. Poesi dreier seg til dømes mellom anna om form og rytme (jf. fagplanen for musikk), og i nokre tilfelle er det ikkje heilt på sida å bruke matematikkens språk i møte med dikt.

Det norskfaglege, kva no det elles måtte vere, ser ut til i nokon grad å bli bytta ut med grunnleggjande ferdigheiter. Historisk sett kan vi peike på mange ulike norskfagskonstruksjonar (Moslet, 2009), eller ulike diskursar om det norskfaglege, og norskfaget blir òg realisert på ulike måtar av ulike lærarar og i ulike skulekulturar (Kjelen, 2013). Norskfaget i Kunnskapsløftet er først og fremst å forstå som eit literacy-fag. I føremålsavsnittet er faget presentert som eit fag for «kulturforståelse, kommunikasjon, dannelse og identitetsutvikling», men meir presist ville det nok vore å seie at norsk er eit fag for utvikling av literacy, og då altså særleg ein fagovergripande literacy. Så lenge literacyomgrepet kan famne om både kulturforståing, kommunikasjon, og til dels danning, skal eg ikkje gjere noko stort poeng ut av dette, men berre peike på følgjande: Faglege innhaldsmoment som til dømes språkhistorie (sjå Hårstad, 2016), skjønnlitterære verk, litteraturhistorie, dialektologi (altså innhald innanfor fenomen-feltet og realia- og kontekstfeltet, jf. Nielsen, 2009), litterær analyse, grammatisk analyse (fagleg metode-felt, jf. Nielsen, 2009), estetiske opplevingar (det personlege og sosiale erfaringsfelt, jf. Nielsen, 2009) osb. kjem i nokon grad i bakgrunnen i fagplanen, og som ein følgje av dette blir norskfaget og fagspesifikke norskfaglege ferdigheiter ikkje tilstrekkeleg tydelege. Norskfaget blir på denne måten ein av skulens hovudleverandørar av nøkkelkompetansar, 
grunnleggjande ferdigheiter eller fagovergripande literacy. For musikkfaget er ikkje dette i like stor grad ei aktuell problemstilling ettersom dei fleste musikkfaglege kompetansane og ferdigheitene i utgangspunktet skil seg frå dei grunnleggjande ferdigheitene som er tekne med i Kunnskapsløftet. Signe Kalsnes skriv i ein artikkel om musikkfaget og grunnleggjande ferdigheiter:

Sett fra en kunstfaglig synsvinkel kan det lett oppfattes som om hele saken er snudd på hodet - at utvikling av kunstfaglig kompetanse nå er betinget av elevenes regne-, skrive-, og lesekompetanse - ikke at kunstfaglig kompetanse er noe vesentlig annet som også kan medføre utvikling av regne-, skrive-, og lesekompetanse. (Kalsnes, 2010, s. 62).

I planen i musikk slik han no føreligg, er det klart at dei som står bak planteksten, mellom andre nemnte Kalsnes, langt på veg har klart å integrere dei grunnleggjande ferdigheitene i det musikkfaglege. Dette er gjort mellom anna ved å bruke særs vide definisjonar av til dømes lesing, skriving og munnlege ferdigheiter. Munnlege ferdigheiter i musikk kan såleis òg handle om å synge.

Den eleven som blir skildra i fagplanen for norsk, er retorikar og strateg. Ho er deltakande og aktiv, talande, skrivande, vurderande, og ho både får svar og svarar på ytringar. Men denne eleven er likevel tilsynelatande aleine i verda, eller på kampplassen om ein vil. I fagplanen for musikk er det individualistiske tona ned, og fellesskap og samhandling er tydelegare skriven inn i planteksten. Den strategiske eleven er ikkje synleg, og individet ser ut til alltid allereie vere ein del av noko større uavhengig av individuell retorisk posisjonering. Denne kontrasten er påfallande og vitnar om stor avstand i fagforståinga hos dei som har utvikla plantekstane. Biletet av fag og elev i fagplanane er sjølvsagt ikkje identisk med læraranes bilete av fag og (ideal)elev, men fagplanane kan likevel få ganske konkrete praktiske konsekvensar. Det handlar til dømes om lærarens val av oppgåver, arbeids- og vurderingsmåtar. Legg læraren opp til arbeidsmåtar som legg vekt på samhandling eller på strategisk og polemisk språkbruk? I kva grad det faktisk er skilnad mellom norsk og musikk i skulen når det kjem til desse spørsmåla, gjenstår å undersøke.

Fagplanane skal no reviderast på nytt. I revisjonsarbeidet bør spørsmåla om faglegheit og grunnleggjande ferdigheiter tenkast gjennom på nytt. Ettersom kjernefaglegheit og djup læring er sentrale stikkord for det arbeidet som no er starta, vil det vere heilt avgjerande å drøfte dette. Særleg for norskfaget sin del er ei gjennomtenking av faggrenser og fagets historie som kultur- og ferdigheitsfag naudsynt. Resultatet av revisjonen burde frå ein norskdidaktisk ståstad bli ei styrking av fagleg innhald og vektlegging av faglege ferdigheiter for slik å gjere tydeleg kva som er spesifikt norskfagleg (jf. Skaftun, Wagner og Aasen, 2015). Eit utydeleg norskfag er verken lærarar eller elevar tent med, og det vil neppe bidra til djupare læring. 


\section{Om forfattaren}

Hallvard Kjelen er førsteamanuensis i norsk. Forskingsinteressar er norskfagets didaktikk, særleg litteraturdidaktikk, skuleutvikling og lese- og skriveopplæring. Var i 2015 redaktør for antologien Det utvidete leringsrommet (Fagbokforlaget).

Institusjon: Fakultet for lærerutdanning og kulturfag, Nord universitet, Postboks 1490, 8049 Bodø.

E-post: Hallvard.Kjelen@nord.no

\section{Referansar}

Alvesson, M \& Sköldberg, K. (2008). Tolkning och reflektion. Vetenskapsfilosofi och kvalitativ metod. Lund: Studentlitteratur.

Berge, K. L. (2005). Skriving som grunnleggende ferdighet og som nasjonal prøve - ideologi og strategier. I A. J. Aasen \& S. Nome (red.). Det nye norskfaget. Bergen: Fagbokforlaget.

DeSeCo (2005). The definition and selection of key competencies: Executive summary. Henta 18. oktober 2017 frå http://www.deseco.admin.ch/bfs/deseco/en/index/02.parsys.43469.downloadList.2296.Do wnloadFile.tmp/2005.dskcexecutivesummary.en.pdf

Engelsen, B. U., \& Karseth, B. (2007). Læreplan for Kunnskapsløftet - et endret kunnskapssyn. Norsk pedagogisk tidsskrift, 91(5), 404-415. Henta frå: https://wwwidunn-no.eazy.uin.no/npt/2007/05/lereplan_for_kunnskapsloftet_et_endret_kunnskapssyn

Gallop, J. (2007). The historicization of literary studies and the fate of close reading. Profession, 181-186.

Goodlad, J. I. (1979). Curriculum Inquiry. The Study of Curriculum Practice. New York: McGraw-Hill Book Company.

Gundem, B. B. (2008). Perspektiv på læereplanen. Bergen: Fagbokforlaget.

Hertzberg, F. (2010). Arbeid med grunnleggende ferdigheter. I E. Ottesen, J. Møller \& P. Aasen (red.). Underveis, men i svcert ulikt tempo. Et blikk inn i ti skoler etter tre år med Kunnskapsløftet (s. 77-89). Oslo: NIFU.

Hårstad, S. (2016). «[...] en enkel og saklig innføring i norsk språkhistorie» Språkhistorie som norskdidaktisk emne - et faghistorisk utsyn. Acta Didactica Norge, 10(3), Art. 9.

Kalsnes, S. (2010). Musikkfaget og de grunnleggende ferdighetene - noen perspektiver på kunnskap. I Sætre, J. H. \& Salvesen, G. (red.). Allmenn musikkundervisning. Oslo: Gyldendal Akademisk.

Karseth, B., \& Sivesind, K. (2009). Læreplanstudier - perspektiver og posisjoner. I Dale, E. L. Lereplan i et forskningsperspektiv (23-61). Oslo: Universitetsforlaget.

Kjelen, H. (2013). Litteraturundervisning i ungdomsskulen. Danning, kanon og kompetanse. (Doktoravhandling) Trondheim: NTNU.

Kress, G. R. (2003). Literacy in the new media age. Psychology Press.

Lagerstrøm, B. O., Moafi, H., \& Revold, M. K. (2014). Kompetanseprofil i grunnskolen. Hovedresultater 2013/2014. SSB rapport, (30).

Meld. St. (2015-2016). (2016). Fag - Fordypning - Forståelse. En fornyelse av Kunnskapsløftet. Oslo: Kunnskapsdepartementet. Henta frå https://www.regjeringen.no/no/dokumenter/meld.-st.-28-20152016/id2483955/ 
Moslet, I. (2009). Norsklærer. I J. Smidt (red.). Norskdidaktikk - ei grunnbok (s. 23-35). Oslo: Universitetsforlaget.

Nielsen, F. V. (2004). Perspektiver på faglighed. Et notat om faglighedsbegreber. I Nielsen, F. V \& Graabræk Nielsen, S. (red.) Nordisk musikkpedagogisk forsking, Årbok 7. (s. 133136). Oslo: Norges Musikkhøgskole.

Nielsen, F. V. (2009). Didaktikkens indholdsbegreb og kriterier for valg af undervisningsindhold. I Hansen, B. G. \& Tams, A. (red.). Almen didaktik. Relationer mellem undervisning og læring (s. 249-271). Værløse: Billesø \& Baltzer.

NOU (2014: 7). Elevenes læring i fremtidens skole. Et kunnskapsgrunnlag. Oslo: Kunnskapsdepartementet.

NOU (2015:8). Fremtidens skole. Fornyelse av fag og kompetanser. Oslo: Kunnskapsdepartementet.

Olsen, S. H. (2003). Litteraturfagets fremskritt. Norsk Litteraturvitenskapelig Tidsskrift, 6, 14-26.

Rogne, M. (2008). Mot eit moderne norskfag. Acta Didactica Norge, 2(1), Art-2.

Rogne, M. (2012). Mot eit moderne norskfag: ein studie i norskfagets tekstomgrep (Doktoravhandling, UiS). Stavanger: Universitetet i Stavanger. Elektronisk utgåve henta frå http://brage.bibsys.no/uis/handle/URN:NBN:no-bibsys_brage_28832

Ruge, H. (1933): Morsmålsundervisningen. Oslo: Cappelen.

Shanahan, T., \& Shanahan, C. (2012). What is disciplinary literacy and why does it matter? Topics in language disorders, 32(1), 7-18.

Skaftun, A., Wagner, Å. K. H. \& Aasen, A. J. (2015). Fagovergripende og fagspesifikke kompetanser i fremtidens skole - en besøkelsestid for norskfaget. Norsklcraren. Tidsskrift for språk, litteratur og didaktikk, 2, 50-60.

Skaftun, A. \& Michelsen, P. A. (2017). Litteraturdidaktikk. Oslo: Cappelen Damm Akademisk.

Skovholt, K. (2014). Grunnleggende ferdigheter i alle fag. I Skovholt, K. (red.). Innføring i grunnleggende ferdigheter. Praktisk arbeid på fagenes premisser (s. 13-54). Oslo: Cappelen Damm Akademisk.

Smidt, J. (2011). Finding Voices in a Changing World: Standard Language Education as a Site for Developing Critical Literacies. Scandinavian Journal of Educational Research, 55(6), 655-669.

Sætre, J. H., Neby, T. B., \& Ophus, T. (2016). Musikkfaget i norsk grunnskole: Læreres kompetanse og valg av undervisningsinnhold i musikk. Acta Didactica Norge, 10(3), Art. 3

Utdanningsdirektoratet (1993). Læreplan for grunnskule, vidaregåande opplæring og vaksenopplæring. Generell del. Henta frå https://www.udir.no/globalassets/upload/larerplaner/generell_del/generell_del_lareplan_n ynorsk.pdf

Utdanningsdiratkoratet (2006a) Læreplanverket for Kunnskapsløftet. Henta frå https://www.udir.no/laring-og-trivsel/lareplanverket/

Utdanningsdirektoratet (2006b). Læreplan i musikk. Henta frå https://www.udir.no/kl06/MUS1-01

Utdanningsdirektoratet (2006c). Læreplanverket for Kunnskapsløftet. Prinsipp for opplæringa Henta frå https://www.udir.no/globalassets/upload/larerplaner/fastsatte_lareplaner_for_kunnskaps loeftet/prinspipper_lk06_nn.pdf

Utdanningsdirektoratet (2012). Rammeverk for grunnleggende ferdigheter. Oslo: Kunnskapsdepartementet. 
Utdanningsdirektoratet (2013). Læreplan i norsk. Henta frå https://www.udir.no/kl06/NOR1$\underline{05}$

Varkøy, Ø. (2010). Musikkopplevelse som eksistensiell erfaring - i Kunnskapsløftet. I Sætre, J. H. \& Salvesen, G. (red.). Allmenn musikkundervisning (s. 23-38) Oslo: Gyldendal Akademisk. ${ }^{1}$ I denne artikkelen brukar eg fagplan om planane for dei einskilde faga, og læreplan om læreplanverket som
heilskap. 